\title{
Production Performance of Local Village Chicken Fed by Agriculture by-product Supplemented with Herbal Probiotics and Mud Clams Extract (Polymesoda erosa) in Kendari-South-East Sulawesi
}

\section{Performans Produksi Ayam Kampung yang Diberi Pakan Mengandung Probiotik Herbal dan Ekstrak Kerang Bakau (Polymesoda erosa) di Kendari, Sulawesi Tenggara}

\author{
T. Saili*, R. Aka, F. A. Auza, W. L. Salido, A. M. Sari, and A. Napirah \\ Departmentof Animal Science, Faculty of Animal Science, \\ Universitas Halu Oleo, Kendari-Indonesia \\ *E-mail: takdir69@yahoo.com \\ (Diterima: 11 Juli 2019; Disetujui: 29 September 2019)
}

\begin{abstract}
Ninety head day old chick (DOC) of local village chicken was used in this experiment to evaluate the effect of agricultural by product-based feed supplemented with herbal probiotics (HP) and mud clams extract (MC) on production performance of local village chicken. A completely randomized design was used with 5 treatments and 4 replications. The treatments consisted of control (R0), $0.75 \% \mathrm{HP}+1.5 \% \mathrm{MC}$ (R1), $1.5 \% \mathrm{HP}+3 \% \mathrm{MC}(\mathrm{R} 2), 2.25 \% \mathrm{HP}+4.5 \% \mathrm{MC}(\mathrm{R} 3)$, and $3.0 \% \mathrm{HP}+6.0 \% \mathrm{MC}(\mathrm{R} 4)$. All chicken was kept in a group of five flocks equipped with feeding and water supply apparatus. The results showed that local village chicken got R2 treatment gave a significantly higher response in feed consumption (32.5gd1) compared to R0 (23.1gd-1), R1 (23.9gd-1), R3 (24.0gd-1), and R4 (21.3gd-1). The daily gain of local village chicken was also significantly higher in R2 treatment (7.4g-1) compared to R0 (4.6gd-1), R1 (4.9gd1), R3 (4.6gd-1), and R4 treatment (4.1gd-1). However, feed conversion resulted from those treatments did not show a significant difference. The lower feed conversion gain in this experiment has existed in R2 treatment (4.0) followed by treatment R1 (4.9), R0 (5.0), R4 (5.2), and treatment R3 (5.4). Therefore, it was concluded that the treatments had a significant effect on feed consumption and daily gain but had no effect on feed conversion of local village chicken. The inclusion level of $1.5 \%$ herbal probiotics and $3 \%$ mud clams extract gave better effect on both feed consumption and daily gain of local village chicken.
\end{abstract}

Keywords: daily gain, feed conversion, herbal probiotics, local village chicken, mud clams

\section{ABSTRAK}

Sebanyak 90 ekor DOC ayam kampung digunakan pada penelitian ini untuk mengevaluasi pengaruh pakan berbahan baku limbah pertanian yang disuplementasi dengan probiotik herbal (HP) dan ekstrak kerang bakau (MC) terhadap performans produksi ayam kampung. Rancangan penelitian yang digunakan adalah rancangan acak lengkap dengan lima perlakuan dan empat ulangan. Perlakuan terdiri atas kontrol (R0), penambahan $0.75 \% H P+1.5 \% M C$ (R1), penambahan $1.5 \% H P+3 \% M C(R 2)$, penambahan $2.25 \% H P+4.5 \% M C$ (R3), dan penambahan $3.0 \% H P+6.0 \% M C$ (R4). Ayam percobaan ditempatkan sebanyak 5 ekor per petak kandang yang dilengkapi tempat pakan dan tempat air minum. Hasil penelitian menunjukkan bahwa ayam percobaan yang mendapat perlakuan R2 mengkonsumsi pakan nyata lebih banyak (32.5g/hari) dibandingkan ayam pada perlakuan R0 (23.1g/hari), R1 (23.9g/hari), R3 (24.0g/hari), and $R 4$ (21.3g/hari). Pertambahan bobot badan harian ayam kampung juga nyata lebih tinggi pada perlakuan $R 2$ (7.4g/hari) dibandingkan perlakuan $R 0$ (4.6g/hari), $R 1$ (4.9g/hari), $R 3$ (4.6g/hari), and R4 (4.1g/hari). Akan tetapi, konversi pakan antar perlakuan tidak menunjukkan perbedaan yang nyata. Konversi pakan terendah pada penelitian ini diperoleh pada perlakuan $R 2$ (4.0) diikuti oleh R1 (4.9), R0 (5.0), R4 (5.2), dan R3 (5.4). Oleh karena itu dapat disimpulkan bahwa perlakuan berpengaruh nyata pada konsumsi pakan dan pertambahan bobot badan tetapi tidak berpengaruh nyata terhadap konversi pakan ayam kampung. Penambahan 1.5\% probiotik herbal dan 3\% ekstrak kerang bakau memberikan hasil yang 
Vol. 21 (3): 327-336

terbaik pada konsumsidan pertambahan bobot badan ayam kampung.

Kata kunci: ayam kampung, kerang bakau, konversi pakan, pertambahan bobot badan, probiotik herbal

\section{INTRODUCTION}

Chickens are a term in Indonesia for domestic chickens that are not cultivated by means of commercial mass cultivation and do not originate from races produced for commercial purposes. Village chickens do not have the term laying or broiler chicken. This is because native chickens lay eggs as well as poultry and have meat like animals in general. The term "native chicken" was originally the opposite of the term chicken, and this designation refers to chickens found loitering around the housing. However, since the development, purification, and breeding programs of several superior local chickens have been carried out, now there are also some superior breeds of native chickens. To distinguish, now known as free-range chicken (short for "chicken is not a race") for free-range chickens that have been selected and maintained with improved cultivation techniques (not just boiled and left to feed themselves). Poultry farming has a large role in supporting the economy of rural communities because it has high adaptability to the environment and its maintenance is relatively easier.

Lately, the symptoms of returning to nature have become an interesting thing. The upper-middle-class society who originally loved everything that was allaround technology now began to change to a natural situation. The tendency of increasing demand for chicken meat and eggs seems to be influenced by this phenomenon. Public perception about native chickens is native chicken, still smells of nature, and has not been contaminated by harmful substances. Eggs and chicken meat sold at more expensive prices tend to be used to meet limited needs, for example for the consumption of household members (in a limited amount), complementing jamu or complementing traditional events (Aswanto, 2010). This condition is an obstacle as well as opportunities for farmers and animal feed entrepreneurs to utilize local feed or agricultural waste that can support the productivity of native chickens.

The feed is the highest cost component in the livestock business, including broiler breeding business that is managed intensively. Local feed ingredients are always associated with cheap prices. However, there are several things that need to be considered in the use of a feed ingredient, such as the amount of availability, nutrient content, price, the possibility of limiting factors such as toxic substances or anti-nutrition substances and whether or not the material is processed before it can be used as animal feed. The availability of local feed in Southeast Sulawesi is quite a lot, especially waste from fisheries which can be processed into fish meal and used as animal feed

One of the feed additive that can be used to achieve optimal and efficient productivity is a probiotics. Probiotics contain components that are needed by animals such as vitamins and enzymes, mannano glisaccharides that can improve the immune system of livestock (Ahmad, 2006). Probiotics are reported to change the movement of mucin and microbial populations in chicken intestines, so that their presence can improve intestinal function and health, increase absorption of food substances and improve the composition of the microflora in the cecum (Mountzouris et al., 2010). Research related to the provision of probiotics to animal feed has been widely carried out. The use of probiotics in feed resulted in an egg production rate of 1,089 eggs / 50 chicken / 10 weeks, feed consumption of $286 \mathrm{~kg} / 150$ chicken / 10 weeks, and feed conversion from 6.10 to 7.30 (Gunawan, 2002).

In Indonesia, mangrove shells (Polymesoda expansa) are reported to be found in the mangrove forests of Papua, 
Table 1. Composition of Feed Materials and Nutrient Content of Research Feed

\begin{tabular}{lcccccc}
\hline Feed Ingredients & $\%$ & KA & PK & LK & SK & Abu \\
\hline Yellow corn (\%) & 43 & 6.54 & 4.08 & 1.74 & 0.40 & 0.85 \\
Fine brain (\%) & 32 & 4.23 & 3.81 & 2.92 & 2.30 & 1.80 \\
Fish flour (\%) & 25 & 3.42 & 12.15 & 0.64 & 0.04 & 5.80 \\
Complete feed (\%) & 100 & 14.20 & 20.04 & 5.31 & 2.75 & 8.45 \\
\hline
\end{tabular}

Description: $\mathrm{KA}=$ Moisture, $\mathrm{PK}=$ Crude Protein, $\mathrm{LK}=$ Crude Fat, $\mathrm{SK}=$ Crude Fiber

Makassar, on the island of Lombok, namely in Sekotong Bay and Kombal Bay (Dwiono, 2003) as well as in the Kendari bay coast where the people call it kalandue. Shellfish contain fat-soluble vitamins (A, D, E and K) and vitamins are water-soluble (vitamins B1, B2, B6, B12). Scallops are also a source of an animal protein belonging to Complete Protein because the high levels of essential amino acids $(85 \%-95 \%)$ of the proteins contained in shellfish become easily digested by the body. Even shellfish have high content of polyunsaturated fats (omega 3 ). As we have seen, omega-3 with its unique characteristics can prevent and reduce cholesterol buildup and attachment of blood spots to the blood vessel walls which are the main causes of deadly heart attacks and strokes (Mina, 2016).

Studies on the use of herbal probiotics and mud clams extracts on free-range chickens are still limited, so we need a study on the productivity of native chickens given herbal probiotics and mud clams extract (Polimesoda erosa) in Southeast Sulawesi.

\section{METHODS}

\section{Time and Location of Research}

The study was conducted for 5 weeks at the Animal Science Technology and Production Laboratory of the Animal Science Faculty of the Halu Oleo University, Kendari.

\section{Research Material}

The material used in the study was 90 unsexing DOC of village chickens. The enclosure used is a stage model plot enclosure which is equipped with a place to eat and drink as many as 20 plots with a length $\mathrm{x}$ width $\mathrm{x}$ height $(40 \mathrm{~cm} \times 30 \mathrm{~cm} \times 37 \mathrm{~cm})$ with each cage filled with 5 chickens.

\section{Research Methods}

The method used in this study was an experiment with a completely randomized design (CRD) of five treatments and four replications $(5 \times 4)$. The treatment consisted of $(\mathrm{R} 0=$ basal feed $+0 \%$ herbal probiotics $+0 \%$ mud clams extract, $\mathrm{R} 1=$ basal feed $+0.75 \%$ herbal probiotics $+1.5 \%$ mud clams extract, $\mathrm{R} 2=$ basal feed $+1,5 \%$ herbal probiotics $+3 \%$ mud clams extract, $\mathrm{R} 3=$ basal feed $+2.25 \%$ herbal probiotics $+4.5 \%$ mud clams extract, $\mathrm{R} 4=$ basal feed $+3 \%$ herbal probiotics $+6 \%$ mud clams extract). The composition of feed ingredients is shown in Table 1.

\section{Data Analysis}

Feed consumption is calculated according to North and Bell (1990), body weight gain (BWG) and feed conversion are calculated by the Anang (2007) formula as follows, and also procedure for making herbal probiotic (Fig. 1).

\section{Feed consumption}

Feed consumption (g/chicken/week)

$=\frac{\text { Feed given }(g)-\text { Residual feed }(g)}{\text { Total of chicken }(e) x \text { Total of days }}$

\section{Body Weight Gain}

$$
\mathrm{BWG}=\frac{B W t-(B W t-1)}{\Delta}
$$




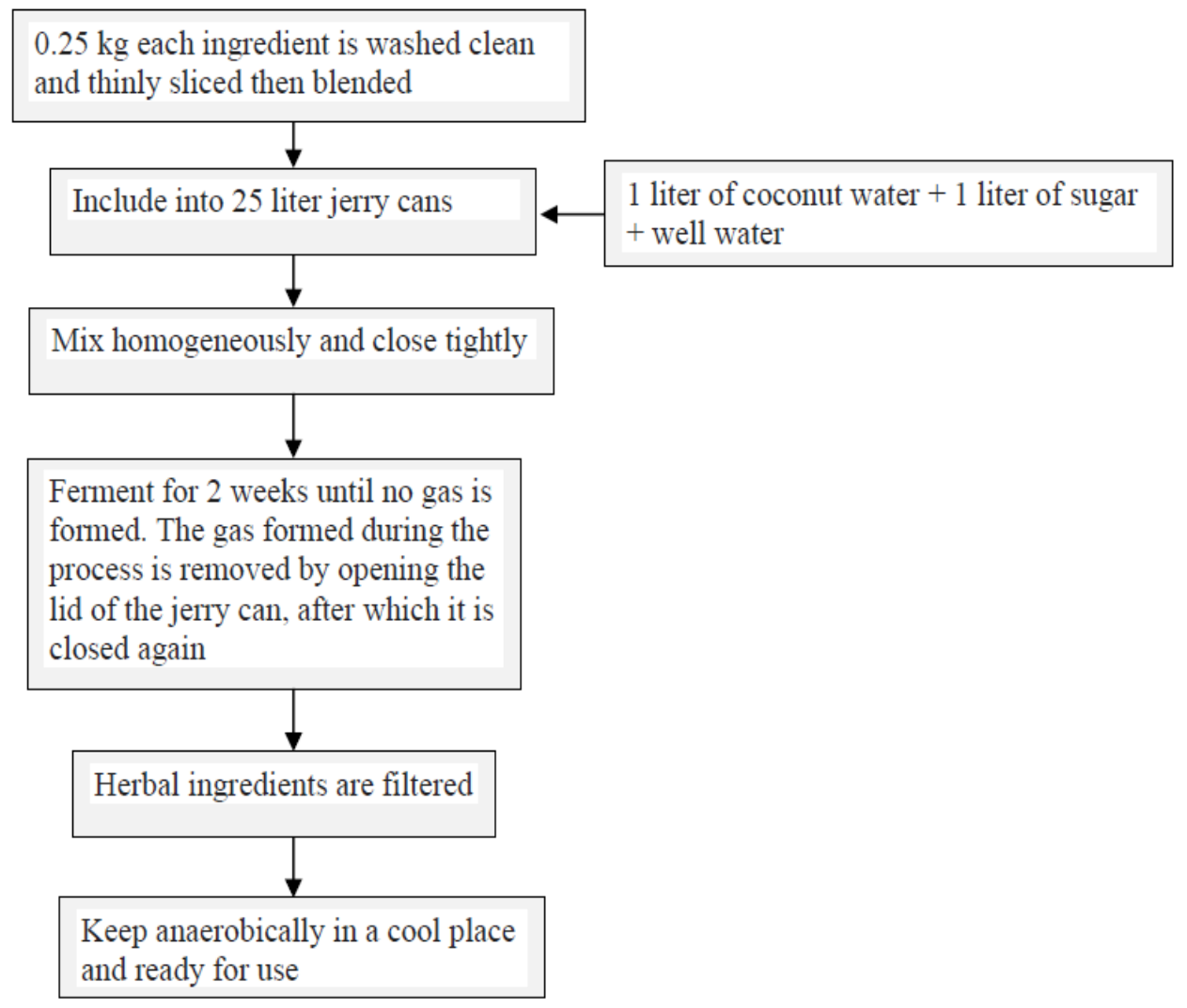

Fig 1. Procedure for Making Herbal Probiotic

Description :

$$
\begin{aligned}
& \mathrm{BWG}=\text { Body Weight Gain }(\mathrm{g}) \\
& \mathrm{BWt}=\text { Body weight at time }(\mathrm{g}) \\
& \text { BWt-1 }
\end{aligned}
$$

\section{Feed Conversion}

$\mathrm{FCR}=\frac{\text { Cumulative amount of feed }}{\text { Body weight of chicken }}$

The data obtained were analyzed using variance analysis and the significant differences between treatments were anayzed using Duncan's Multiple Range Test (Gasperz, 1994).

\section{RESULTS AND DISCUSSION}

The 5-week study data which included average consumption, body weight gain and feed conversion were presented in Table 2.

\section{Feed Consumption}

The results of variance analysis showed that treatments gave a significant effent $(\mathrm{P}$ $<0.05$ )on feed consumption. Feed consumption in $\mathrm{R} 2$ was significantly higher $(\mathrm{P}<0.05)$ than other treatments. This is presumably because the combination of turmeric, ginger, and noni as herbal probiotics added to the feed contains bioactive compounds such as curcumin, essential oils, flavonoids, alkaloids, anthraquinones and saponins which help digestive enzymes work so that it can increase feed consumption and increase the body's metabolic efficiency (Setyanto et al., 2012). While mud clams extract also contains the same bioactive compounds as the combination of herbal ingredients used, namely alkaloids and flavonoids which have antiresistant properties against salmonella bacteria causing E. coli (Marjuki et al., 2012). 
Table 2. Average of feed consumption, body weight gain, and feed conversion of village chicken

\begin{tabular}{lccccc}
\hline Measured & \multicolumn{5}{c}{ Treatment } \\
\cline { 2 - 6 } Parameters & R0 & R1 & R2 & R3 & R4 \\
\hline Feed Consumption & $23.06 \pm 1.65^{\mathrm{a}}$ & $23.92 \pm 2.49^{\mathrm{a}}$ & $32.55 \pm 3.97^{\mathrm{b}}$ & $24.01 \pm 1.97^{\mathrm{a}}$ & $21.27 \pm 1.30^{\mathrm{a}}$ \\
(g) & & & & & \\
PBBH (g/day) & $4.64 \pm 0.41^{\mathrm{a}}$ & $4.90 \pm 0.80^{\mathrm{a}}$ & $7.41 \pm 1.86^{\mathrm{b}}$ & $4.59 \pm 0.97^{\mathrm{a}}$ & $4.14 \pm 0.64^{\mathrm{a}}$ \\
FCR & $4.98 \pm 0.32$ & $4.92 \pm 0.33$ & $4.03 \pm 0.32$ & $5.39 \pm 1.13$ & $5.22 \pm 0.68$ \\
\hline
\end{tabular}

Description: Different superscripts on the same line show significant differences $(\mathrm{P}<0.05)$. (R0 $=$ basal feed $+0 \%$ herbal probiotics $+0 \%$ mud clams extract, $\mathrm{R} 1=$ basal feed $+0.75 \%$ herbal probiotics + $1.5 \%$ mud clams extract, $\mathrm{R} 2=$ basal feed $+1.5 \%$ herbal probiotics $+3 \%$ mud clams extract, $\mathrm{R} 3=$ basal feed $+2.25 \%$ herbal probiotics $+4.5 \%$ mud clams extract, $\mathrm{R} 4=$ basal feed $+3 \%$ herbal probiotics $+6 \%$ mud clams extract

Besides, turmeric and ginger contain good taste or odor that can increase feed palatability and feed efficiency. This is consistent with the opinion of Karyadi (1997) which states that every plant that contains active compounds such as essential oils, saponins, flavonoids, and tannins which can increase the digestibility of nutrients in the digestive tract so that food substances are consumed can be absorbed and utilized optimally for the formation of body tissue production and reproduction. Besides, feed consumption was significantly different $(\mathrm{P}<0.05)$ was also caused by lactic acid bacteria (LAB), namely Lactobacillus casei found in coconut water which was used as a fermentation medium in a combination of herbal ingredients as probiotics. This is in line with the statement of Budiansyah (2004) that probiotics competes with food and produces antimicrobial substances. Probiotic microbes inhibit pathogenic organisms to the competition.

The average consumption of native chicken in the treatment was $23.06 \pm 1.65$ gr (R0), $23.92 \pm 2.49$ gr (R1), $32.55 \pm 3.97$ gr (R2), $24.01 \pm 1.97$ gr (R3), $21.27 \pm 1.30$ gr (R4). The average consumption of chicken in R4 treatment was significantly lower than other treatments. It seems that higher-level of herbal probiotics decreased ration palatability so that the ability of chicken to consume rations was reduced. This is thought to be due to turmeric, ginger, and noni containing essential oils with a distinctive odor, bitter and spicy taste that reduces appetite. The use of probiotics above $2.5 \mathrm{cc} / 1$ of drinking water tends to decrease performance, it is thought that the excess number of microorganisms in the digestive tract may actually use host nutrients (Agustina et al., 2007).

Feed consumption is the amount of feed consumed by livestock (Parakkasi, 1999). The form of feed given is in the form of pellets. According to Krisnan and Ginting (2009), chicken feed in pellets form can improve the appetite for chicken, and each pellet contains the same nutrients so that the feed formula becomes efficient and chickens are not given the opportunity to pick and choose the preferred feed. Palatability is one of the factors influencing feed consumption (Church and Pond 1998). Palatability depends on several things, namely appearance and form of feed, smell, taste, texture, and temperature of the environment. Feed consumption can be affected by the quality and quantity of ration, age, livestock activity. ration palatability, level of production and management. Chemical composition and dietary diversity are closely related to feed consumption (Wahju, 1992).

Probiotics in chickens cause chicken digestion to be better. According to Kompiang (2009), probiotics increase the activity of digestive enzymes so that the absorption of food becomes more perfect with the broader absorption area because probiotics can affect 
intestinal anatomy, namely the intestinal villi become longer and denser in density. Where the absorption process of digestion occurs on the surface of villi which has many microvilli (Suprijatna et al., 2005). This statement was also confirmed by Jin et al. (1997) which states that the presence of probiotics in rations can increase enzymatic activity and increase digestive activity. As a result, nutrients such as fat, protein, and carbohydrates that are usually wasted in feces will be reduced. Furthermore, Alpian et al. (2016) reported that probiotic bacteria are able to reduce $\mathrm{pH}$ in the intestine, facilitate digestion by producing several digestive enzymes and vitamins, and producing antibacterial substances such as organic acids, bacteriocins, $\mathrm{H}_{2} \mathrm{O}$ and other substances.

\section{Body Weight Gain (BWG)}

Bodyweight gain is an indicator of growth achieved in research. This is in line with the opinion of Soeharsono (1997) that weight gain is an easier benchmark to give a clear picture of growth.

The results of the variance analysis showed significant differences $(\mathrm{P}<0.05)$ on body weight gain in R2 compared to other treatments, namely R0, R1, R3, and R4. The highest average body weight gain was achieved in R2 treatment (basal feed $+1.5 \%$ herbal probiotics $+3 \%$ mud clams extract) which was $7.41 \pm 1.86$ gr. This average value is higher than the ideal body weight of 5-week old chickens of 5.13 gr (Muslim, 2012), followed by R1 $(4.90 \pm 0.80 \mathrm{~g}), \mathrm{R} 0$ $(4.64 \pm 0.41 \mathrm{~g}), \mathrm{R} 3(4.59 \pm 0.97 \mathrm{~g})$ and $\mathrm{R} 4$ $(4.14 \pm 0.64 \mathrm{~g})$. This significant difference is thought to be influenced by the amount of feed consumption, which means that high weight gain is influenced by the amount of feed consumed by chicken.

The combination of extracts of herbal ingredients (turmeric, ginger and noni) as probiotics in addition to containing bioactive substances that are anti-bacterial, herbal ingredients contain essential oils that play a role in improving the work of the digestive organs by keeping the intestinal microflora in a stable state, stimulating the bile wall to secrete bile and stimulates the release of pancreatic sap containing amylase, lipase and protease enzymes to improve digestion of carbohydrate, fat and protein feed ingredients. This can be seen from the chickens that were treated with herbal probiotics healthier, active and agile compared to controls (R0). This is in accordance with the opinion of Guenther (1997) that essential oils can help digestion by stimulating nervous system so that gastric enzymes such as pepsin, trypsin, lipase, and amylase secreted into the stomach and intestine to increase metabolism of food substances.

Antibacterial can lyse toxins that attach

to the intestinal wall which make absorption of nutrients becomes better, as the anti-biotic mechanism works as a growthpromoting (Anggorodi, 1985). This is in accordance with the opinion of Ensminger et al. (1992) that rapid growth is sometimes supported by many rations. This is supported also by the opinion of Wahju (1992) that in order to achieve optimal growth rates in accordance with genetic potential, feeds containing nutritional elements are needed qualitatively and quantitatively. Thus there is a relationship between growth rate and the amount of feed intake.

Provision of herbal probiotics, namely turmeric, ginger and noni with a medium of fermentation of coconut water into the ration, will help digestion of food substances in the small intestine and reduce the population of pathogenic bacteria. This is in line with that reported by Yu et al. (2008), that the addition of probiotics to chicken rations can increase the production of $\beta$-glucanase enzymes in all segments of the digestive tract, reduce digicyclic viscosity and can increase body weight gain. Besides that mud clams extract used in rations has a high nutritional value and contains bioactive compounds. This is in accordance with the opinion of Marjuki et al. (2012), that the nutrient content of mud clams (Polymesoda erosa) was $12.43 \%$ 
protein, $4.12 \%$ fat, $3.60 \%$ carbohydrate, $77.08 \%$ moisture content and $2.77 \%$ ash content. Test results of bioactive compounds of crude extracts of mud clams are alkaloids, flavonoids, steroids, and ninhydrin

The treatment of $\mathrm{R} 4$ (basal ration $+3 \%$ herbal probiotics $+6 \%$ mud clams extract) was real $(\mathrm{P}<0.05)$ lower than the treatments $\mathrm{R} 0, \mathrm{R} 1, \mathrm{R} 2$, and R3. This is probably due to the high level of herbal probiotics and mud clams extract so that the consumption of feed and palatability of native chickens decreases due to the bitter aroma and taste of herbal ingredients containing curcumin and essential oils, especially turmeric and ginger. Liang et al. (1985) reported that the chemical content of turmeric (curcumin) in the chicken's body tends to play a role in decreasing fat so that the weight of life decreases. Awang et al. (1992) reported that administration of curcumin 10 $\mathrm{mg} / \mathrm{kg}$ ration on broiler chickens can only increase the yellow color of chicken skin. Sunaryo et al. (1992) stated that the content of curcumin in turmeric can reduce cholesterol levels in rats.

The effect of reduced absorption of food substances in the digestion of native chickens is influenced by the presence of tannin in noni fruit which is known as an anti-nutrient substance which if given excessively will result in a decrease in the ability of animals to digest protein and carbohydrates (Magdalena, 2013). Djauhariya and Tirtoboma (2001) stated that Noni contains several anti-nutrient compounds that can inhibit growth, one of which is tannin.

The use of mud clams extracts with high doses can cause problems for body health. This may be due to the mud clams being habitats in brackish water that are sedentary, slow to avoid the effects of pollution and have a high concentration of certain metal concentrations. Heavy metal is very dangerous because it can disturb metabolism, toxic for physiological functions, and in the long run, it creates digestive problems, decreases HDL and causes damage to the immune system (Suryono, 2016).

\section{Feed Conversion}

Feed Converting Ratio (FCR) is calculated by dividing the value of feed consumption with body weight gain. Feed conversion shows the efficiency of ration use in broiler chickens. The ration provided gives output as body weight gain in accordance with the standard chicken seed production used. The value of feed conversion will be better if it has a smaller value (Rasyaf, 1994). Based on the result of variance analysis, the treatments had no significant effect on feed conversion ratio of village chicken. It was indicated that feed conversion ratio between treatments were not significantly different. Although there were no significant differences between treatments, feed conversion in R2 (basal ration + herbal probiotics $1.5 \%+$ mud clams extract $3 \%$ ) was lower than other treatments, which were 4.03 \pm 0.32 . Then followed respectively R1 (4.92 $\pm 0.33), \mathrm{R} 0(4.98 \pm 0.32), \mathrm{R} 4(5.22 \pm 0.68)$, $\mathrm{R} 3(5.39 \pm 1.13)$. This is an indication that the administration of probiotics gives little influence on the conversion of native chicken feed. This shows that the administration of herbal probiotics and mud clams extracts in chicken feed can affect the efficiency of feed use so that the rate of chicken feed conversion becomes low.

The feed conversion value obtained in this study is higher than the value of feed conversion of native chickens given zeolite (Simangunsong, 2014) which is $3.61 \pm$ 0.17 . Feed conversion of free-range native chickens ranged from 4.90 to 6.90. (Suryana and Hasbianto, 2008). This shows that the conversion of feed obtained is still in the normal standard which ranges from 4.92 - 5.39. According to Amrullah (2004), the factors that influence feed conversion are the quality of ration, age, and strain.

Probiotics in chickens cause chicken digestion to be better. According to Andoko (2005), the function of probiotics is to perfect the metabolic process so that if the metabolism is smooth, the food substances can be absorbed properly and result in growth not being inhibited. One thing that shows that 
probiotics benefit native chickens, because there were no deaths in the treatment of herbal probiotics + mud clams extracts, whereas in the control treatment (without probiotics) there were 3 deaths due to cold weather. This is in line with the statement of Budiansyah (2004) that probiotics competing with feed and producing antimicrobial substances.

Probiotic microbes inhibit pathogenic organisms to compete. Furthermore, Lopez (2000) stated the probiotics are living microorganisms; not absorved in the digestive tract; no tissue residue; cause no mutation of other microorganisms and as it is performed by antibiotics they improve growth and feed efficiency. Viable bacteria such as the Lactobacillus species, Bacillus subtilis, Streptococcus species are the most directfed microbials. He will identify dangerous pathogens and other foreign substances in the body. During this process, immune cells and antibodies will cooperate in the bloodstream to stop the spread of bad viruses and bacteria (Fuller, 1992).

Feed conversion is a comparison between the number of negative microorganisms. The immune system is consumed by weight gain in one week. Feed conversion is needed to illustrate the extent of the biological effectiveness of the utilization of nutrients in the feed (Wiryawan et al., 2005). In other words, feed conversion is intended to assess the efficiency of feed use in livestock. Lestari (1992) states that if the feed conversion ratio (FCR) is smaller which is close to 1 then the feed used is more efficient and vice versa if the FCR is large then the use of feed is not efficient.

\section{CONCLUSIONS}

\section{Conclusion}

From the results of the discussion above, it can be concluded as follows:

1. The inclusion of herbal probiotics and mud clams extracts gave the significant effect on feed consumption and body weight gain of village chicken but not in feed conversion.

2. The feed consumption and body weight gain of village chicken in treatment R2 were significantly higher than treatment R3 and R4, but not significantly different from treatment R0 and R1.

3. The treatment R2 gave the best results in feed consumption and body weight gain of village chicken.

\section{Suggestion}

Further research is needed on the effectiveness of a combination of herbal probiotics and mud clams extract in feed and drinking water of native chickens to increase livestock production and productivity based on fishery waste.

\section{REFERENCE}

Agustina, L., S. Purwanti, and Zainuddin. 2007. Use of Probiotics (Lactobacillus sp.) As broiler feed additives. National Seminar on Animal and Veterinary Technology.

Ahmad, I. 2006. Effect of Probiotic on Broiler Performance. Int. J. Poult Sci., 5(6): 593-597.

Amrullah, I. K. 2004. Broiler Chicken Nutrition. Gunung Budi Satu Institute KPP IPB Banangsiang, Bogor.

Anang, A. 2007. Harvest native chicken in 7 weeks. Print 1. Penebar Swadaya, Jakarta.

Andoko. 2005. Probiotic idol supplements today. http:/group.yahoo.com/goup/ ikan ornamental (October 2005).

Anggorodi, R. 1985. Recent Advance in Poultry Nutrition Science. Universitas Indonesia Press, Jakarta.

Aswanto. 2010. Raising Village Chicken. Institute for Agricultural Technology Assessment. West Kalimantan.

Awang, I.P.R., U. Chulon, and F.B.H. Akaraol. 1992. Curcuma for up gading skin 
colour nutrition. Abstract and review. $\mathrm{CAB}$, International.

Budiansyah, A. 2004. The use of Probiotic for improving poultry production performance. Makalah Falsafah Sains. Program Pasca sarjana, Institut Pertanian Bogor

Church, D., and W.G. Pond. 1998. Basic Animal Nutrition and Feeding. 3rd Ed. John Wiley and Sons, New York.

Djauhariya, E. and Tirtoboma. 2001. Noni (Morinda citrifolia) Traditional Multi Medicinal Plants. News of Agicultural Research and Development 7: 1-7.

Dwiono, S.A.P. 2003. Introduction to mud shell, Geloina erosa dan Geloina expansa. Oseana, XXVIII: 31-38.

Ensminger. M. E., J. E. Oldfield, and W. W. Heinemann. 1992. Feeds and Nutrition. 2nd Edition. Ensminger Publishing Company, California, USA.

Fuller. 1992. Probiotic the Scientific Basis. 1st ED. Chapman and Hall London, New York.

Guenther, E. 1997. Atsiri Oil. Ketaren. Universitas Indonedia, Jakarta.

Gunawan. 2002. Evaluation of the Model of Hatching Chicken Livestock Business Development and Improvement Efforts. Dissertation. Bogor Agicultural University Postgaduate Progam.

Jin, L.Z., Y.W. Ho, N. Abdullah and S. Jalaludin. 1997. Probiotics in poultry : Modes of Action. World's Poultry Science Journal, 53:351-368.

Karyadi, E. 1997. Phytochemical role on health. PT. Gramedia, Jakarta, Pp. 15.

Kompiang, I.P. 2009. Utilization of microorganisms as probiotics to increase poultry production in Indonesia. Development of Agicultural Innovation, 2(3):177-191.

Krisnan, R. dan S.P. Ginting. 2009. Use of Solid Ex-Decanter as Adhesives for Making Complete Pellet-Shaped Feeds: Physical Evaluation of Complete Pellet-
Shaped Feeds. Journal of Technology and Veterinary, 480-486.

Lestari. 1992. Determine Broiler Seedlings. Indonesian Animal Husbandry. Bogor.

Liang, O.B., Y. Apsarton, Y. Widjaja and Puspa. 1985. Some aspects of isolation and use of component components of Curcuma xanthorhiza roxb. and Curcuma domestica val. Proc. Symposium. Temulawak National. UNPAD Research Institute, Bandung. Pp. 85-92.

Lopez. 2000. Probiotic in Animal Nutrition. Asian-Aust. J. Anim.Sci. 13, Special issue:12-26 http://www.biotec.lipi. go.id.

Magdalena, S., G.H. Natadiputri, F. Nailufar, and T. Purwadaria. 2013. Utilization of Natural Products as Functional Feeds. Wartazoa Journal, 23(1).

Marjuki. K, H. Hafiluddin and H. Triajie. 2012. Nutritional Content Analysis and Bioactive Snail Compound (Telescopium telescopium) in the Waters of Bangkalan Regency and Socah. Jurnal Kelautan, 5(1).

Mina, W.2006. Nutritionand Shellfish Benefits. http: /// D: /Proposal\%20Insinas \%20 fuji\%202017/Probiotik\%20herbal/ Wicara\%20Mina_\%20nutrisi\%20 dan\%20manfaat\%20kerang. Htm1. (April 10, 2017).

Mountzouris, K.C., P. Tsitrsikos, I. Palamidi, A. Arvaniti, M. Mohnl, G. Schatzmayr, and K. Fegeros. 2010. Effects of probiotic inclusion levels in broiler nutrition on growth performance, nutrient digestibility, plasma immunoglobulins, and cecal microflora composition. Poult. Sci., 89:58-67

Muslim. 2012. Farming Village Chicken on Battery System. http://dogiay. blogspot. com/2012/01/pemelih-ayam-kampungumur-2-6-minggu.html. (May 2018).

North, M.O. and P.B. Bell. 1990. Commercial Chicken Production Manual. Avi 
Publishing Company Inc. Westport. Connecticut

Parakkasi, A. 1999. Nutrition and Ruminant Food Science. Jakarta: University of Indonesia Publisher.

Rasyaf, M. 1994. Broiler Chicken Food. Kanisius, Yogyakarta.

Setyanto, A., U. Antomomarsono dan R. Muryani. 2012. The Influence of the Use of Emprit Ginger (Zingiber officinale var Amarum) Flour in the Ration Against the Feed Rate and Digestibility of 12 Weeks of Village Chicken Feed. Diponegoro University Faculty of Animal Husbandry and Agriculture. Semarang. http:// ejournals1.undip.ac.id/index.php /aaj/ article/view/813/787. (12 Mei 2013).

Simangunsong, R.J. 2014. Performance of Village Chicken Given Zeolite in its ration. [Skripsi], Bogor Agricultural Institute.

Soeharsono, 1997. Alternative Probiotics to Substitute Antibiotics in the Field of Animal Husbandry. Faculty of Animal Husbandry, Padjadjaran University, Bandung.

Sunaryo, H., S.P. Ediyanto, W. Djatmiko and A. Fuad. 1992. Effect of curcuminoid (Curcuma domestica val.) Administration on serum HDL cholesterol levels of white rats (Rattus novergicus). UNAIR Traditional Medicine Research Center, Surabaya.

Suprijatna, E., U. Atmomarsono., dan R. Kartasudjana. 2005. Basic Science of Poultry. Penebar Swadaya, Jakarta.

Suryana dan A. Hasbianto. 2008. Freerange Chicken Farming in Indonesia: Problems and Challenges. Pertamina Research and Development Journal. 27 (3):75-83.

Suryono, C. A,. 2016. Accumulation of $\mathrm{Cr}, \mathrm{Pb}$ and $\mathrm{Cu}$ heavy metals in sediment and their relationship with basic organisms in the waters of Tugu Semarang., Journal of Tropical Marine, 19(2):143-149.

Wahju, J. 1992. Ilmu Nutrisi Unggas. Penerbit Gadjah Mada University Press, Yogyakarta

Wiryawan, K.G., M. Sinarsih and D.P. Winata. 2005. Appearance of Broilers Given Probiotics (EM-4) as Substitutes for Antibiotics. Thesis. Faculty of Animal Science, University of Mataram. West Lombok.

Yu, B., J.R. Liu, F.S. Hsiao and P.W.S. Chiou. 2008. Evaluation of Lactobacillus Reuteri Pg4 Strain Expressing Heterologous B-glucanase as a Probiotic in Poultry Diets Based on Barley. Anim Feed Sci and Tech., 141:82-91. 